\title{
The L. L. Winterbauer Site (41WD6), Wood County, Texas
}

Timothy K. Perttula

Heritage Research Center, Stephen F. Austin State University

Follow this and additional works at: https://scholarworks.sfasu.edu/ita

Part of the American Material Culture Commons, Archaeological Anthropology Commons, Environmental Studies Commons, Other American Studies Commons, Other Arts and Humanities Commons, Other History of Art, Architecture, and Archaeology Commons, and the United States History Commons

Tell us how this article helped you.

This Article is brought to you for free and open access by the Center for Regional Heritage Research at SFA ScholarWorks. It has been accepted for inclusion in Index of Texas Archaeology: Open Access Gray Literature from the Lone Star State by an authorized editor of SFA ScholarWorks. For more information, please contact cdsscholarworks@sfasu.edu. 


\section{The L. L. Winterbauer Site (41WD6), Wood County, Texas \\ Creative Commons License \\ (c) (1) (9)}

This work is licensed under a Creative Commons Attribution-NonCommercial 4.0 International License 


\title{
The L. L. Winterbauer Site (41WD6), Wood County, Texas
}

\author{
Timothy K. Perttula
}

\section{INTRODUCTION}

The L. L. Winterbauer site (41WD6) is an ancestral Caddo habitation site in the Lake Fork Creek basin in the Post Oak Savannah of East Texas (Figure 1). It is situated along a small tributary stream that flows west into Lake Fork Creek, itself a tributary to the Sabine River, about 1.5 miles west of Quitman, the county seat of Wood County. The recovered artifacts from the investigations of the Winterbauer site indicate that the site was occupied during the Late Caddo period Titus phase, dated generally between ca. A.D. 1430-1680.

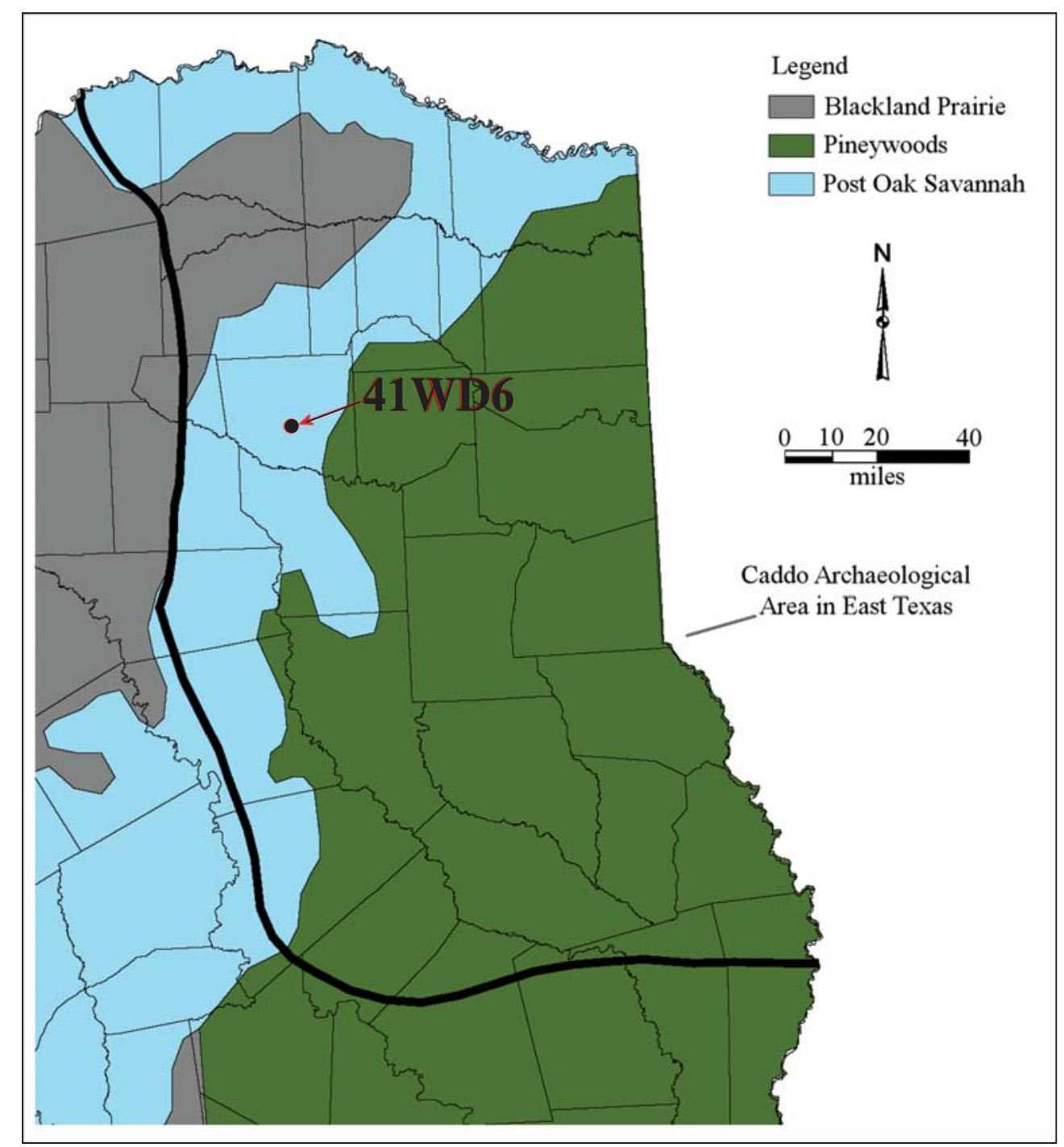

Figure 1. The location of the L. L. Winterbauer site (41WD6) in East Texas. 


\section{SITE SETTING AND INVESTIGATIONS}

Wilson and Jackson (1930) excavated a midden mound at the Winterbauer site in August 1930. The midden mound was estimated to be ca. $12.2 \mathrm{~m}$ in diameter and ca. $0.6 \mathrm{~m}$ in height. Wilson and Jackson (1930) describe it as a "kitchen midden mound and yielded many bones, a large quantity of shard [sic], deer antlers, mussel shells, ashes and charcoal." No cultural features were identified in the midden mound, and Wilson and Jackson (1930) did not look for preserved evidence of habitation features in areas in proximity to the midden mound.

Wilson and Jackson (1930) did make note of the provenience of certain remains in the midden mound, including turtle shells in the northwestern part of the midden, and a bone-tempered elbow pipe at a depth of ca. $13 \mathrm{~cm}$ bs in the northeastern part of the midden (Figure 2). There were also a total of nine canid skulls, probably marking the deliberate burial (or disposal) of dogs in the midden deposits, in the southern part of the midden mound.

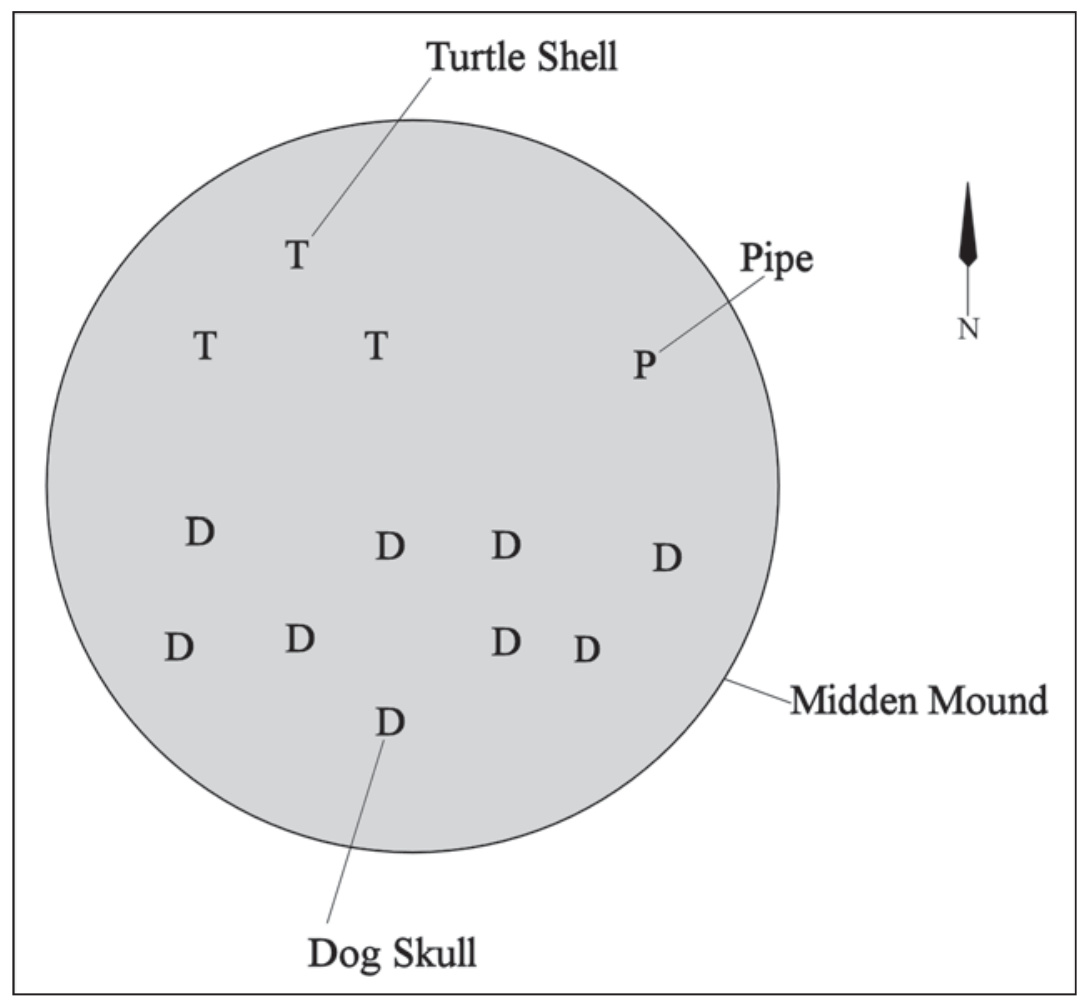

Figure 2. Location of distinctive finds in the Winterbauer midden excavations.

\section{ARTIFACT ASSEMBLAGE}

In addition to 916 ceramic sherds from the midden mound at the Winterbauer site in the collections at the Texas Archeological Research Laboratory at The University of Texas, there were clay coil fragments, lumps of kaolin clay, and an engraved elbow pipe. There were also animal bones $(n=99)$ from turtle, deer, birds, and other mammals, dog crania, and two possible bison bones: a long bone fragment and a mandible of a juvenile. Freshwater mussel shell valves $(n=13)$ were also collected by Wilson and Jackson (1930). 


\section{Ceramic Sherds}

The ceramic assemblage includes sherds from plain ware ( $\mathrm{n}=708 ; 661$ body sherds, 18 rim sherds, and 29 base sherds) vessels as well as 208 sherds from decorated utility ware $(n=149)$ and fine ware $(n=59)$ vessels (Table 1). Utility wares comprise 72 percent of the decorated sherds, dominated by sherds from neck banded, appliqued, and incised vessels. The fine wares include sherds from both engraved and slipped vessels. About 4.8 percent of the sherds are from bone-tempered vessels, with the remaining 95.2 percent of the sherds being from vessels tempered with grog or crushed sherds.

Table 1. Decorated sherds from the L. L. Winterbauer site.

\begin{tabular}{|c|c|c|c|c|c|}
\hline \multirow[b]{2}{*}{ Decorative method } & \multicolumn{2}{|c|}{ Grog } & \multicolumn{2}{|c|}{ Bone } & \multirow[b]{2}{*}{$\mathrm{N}$} \\
\hline & rim & body & rim & body & \\
\hline \multicolumn{6}{|l|}{ Utility ware } \\
\hline Appliqued & - & 31 & - & 2 & 33 \\
\hline Appliqued-Punctated & 1 & 1 & 1 & - & 3 \\
\hline Brushed & 1 & 5 & - & 1 & 7 \\
\hline Brushed-Incised & - & 1 & - & - & 1 \\
\hline Grooved & 3 & - & - & - & 3 \\
\hline Incised & 8 & 16 & - & 2 & 26 \\
\hline Incised-Punctated & 1 & 1 & - & - & 2 \\
\hline Lip notched & 2 & - & - & - & 2 \\
\hline Neck Banded & 17 & 38 & 1 & - & 56 \\
\hline Neck Banded-Appliqued & 6 & - & - & - & 6 \\
\hline Neck Banded-Punctated & 1 & - & - & - & 1 \\
\hline Punctated, fingernail & 1 & - & - & - & 1 \\
\hline Punctated, tool & 2 & 6 & - & - & 8 \\
\hline Subtotal & 43 & 99 & 2 & 5 & 149 \\
\hline \multicolumn{6}{|l|}{ Fine ware } \\
\hline Engraved & 14 & 36 & 1 & 1 & 52 \\
\hline Red-slipped & - & 6 & - & 1 & 7 \\
\hline Subtotal & 14 & 42 & 1 & 2 & 59 \\
\hline Totals & 57 & 141 & 3 & 7 & 208 \\
\hline
\end{tabular}

The principal decorative methods in the utility ware sherds from the L. L. Winterbauer site are sherds from neck banded ( 38 percent of the utility wares), appliqued ( 22 percent), and incised (18 percent) vessels (see Table 1). About 88 percent of the fine ware sherds have engraved decorative elements, and the remainder have red-slipped vessel surfaces (see Table 1).

The appliqued body sherds with a straight appliqued fillet or straight appliqued ridge (Table 2) are from McKinney Plain jars (Suhm and Jelks 1962:97 and Plate 49); the fillets and ridges would have vertically bisected the vessel body. The three appliqued-punctated rim and body sherds are also from McKinney Plain vessels, with a punctated row below the lip and adjacent appliqued nodes and/or vertical appliqued ridges (Figure 3d). The body sherd with closely-spaced appliqued ridges is from a Harleton Appliqued jar (see Suhm and Jelks 1962:Plate 33c-d, g), while the three body sherds with closely-spaced diagonal opposed appliqued ridges (Figure 3e) are from at least two Cass Appliqued jars (see Suhm and Jelks 1962:25 and Plate 13a-a'). 
Table 2. Decorative elements in utility ware sherds from the L. L. Winterbauer site.

\begin{tabular}{|c|c|c|c|c|c|}
\hline \multirow[b]{2}{*}{ Decorative method } & \multicolumn{2}{|c|}{ Grog } & \multicolumn{2}{|c|}{ Bone } & \multirow[b]{2}{*}{$\mathrm{N}$} \\
\hline & rim & body & rim & body & \\
\hline \multicolumn{6}{|l|}{ Appliqued } \\
\hline straight fillet & - & 1 & - & - & 1 \\
\hline $\begin{array}{l}\text { closely-spaced diagonal opposed } \\
\text { ridges }\end{array}$ & - & 1 & - & 2 & 3 \\
\hline closely-spaced parallel ridges & - & 1 & - & - & 1 \\
\hline straight ridge & - & 28 & - & - & 28 \\
\hline \multicolumn{6}{|l|}{ Appliqued-Punctated } \\
\hline $\begin{array}{l}\text { tool punctated row below lip, } \\
\text { vertical appliqued ridge, and } \\
\text { set of two appliqued nodes }\end{array}$ & 1 & - & - & - & 1 \\
\hline $\begin{array}{l}\text { tool punctated row and adjacent } \\
\text { appliqued node }\end{array}$ & - & 1 & - & - & 1 \\
\hline $\begin{array}{l}\text { diagonal fingernail punctated row } \\
\text { under lip and adjacent appliqued } \\
\text { node }\end{array}$ & - & - & 1 & - & 1 \\
\hline \multicolumn{6}{|l|}{ Brushed } \\
\hline horizontal brushed & 1 & - & - & - & 1 \\
\hline parallel brushed & - & 5 & - & 1 & 6 \\
\hline \multicolumn{6}{|l|}{ Brushed-Incised } \\
\hline $\begin{array}{l}\text { parallel brushed with overlying } \\
\text { diagonal incised line }\end{array}$ & - & 1 & - & - & 1 \\
\hline \multicolumn{6}{|l|}{ Grooved } \\
\hline horizontal grooved lines & 3 & - & - & - & 3 \\
\hline \multicolumn{6}{|l|}{ Incised } \\
\hline cross-hatched lines & 2 & 5 & - & - & 7 \\
\hline diagonal lines, R-L & 1 & - & - & - & 1 \\
\hline diagonal lines, L-R & 1 & 1 & - & - & 2 \\
\hline diagonal opposed lines & 3 & 3 & - & - & 6 \\
\hline horizontal line under lip & 1 & - & - & - & 1 \\
\hline parallel lines & - & 5 & - & 1 & 6 \\
\hline straight line & - & 2 & - & 1 & 3 \\
\hline $\begin{array}{l}\text { Incised-Punctated } \\
\text { diagonal incised lines and } \\
\text { triangular zone filled with } \\
\text { tool punctations }\end{array}$ & 1 & 1 & - & - & 2 \\
\hline Lip Notched & 2 & - & - & - & 2 \\
\hline
\end{tabular}


Table 2. Decorative elements in utility ware sherds from the L. L. Winterbauer site, cont.

\begin{tabular}{|c|c|c|c|c|c|}
\hline \multirow[b]{2}{*}{ Decorative method } & \multicolumn{2}{|c|}{ Grog } & \multicolumn{2}{|c|}{ Bone } & \multirow[b]{2}{*}{$\mathrm{N}$} \\
\hline & rim & body & rim & body & \\
\hline \multicolumn{6}{|l|}{ Neck Banded } \\
\hline horizontal neck banding & 17 & 38 & 1 & - & 56 \\
\hline \multicolumn{6}{|l|}{ Neck Banded-Appliqued } \\
\hline $\begin{array}{l}\text { horizontal neck banding and } \\
\text { vertical appliqued ridges }\end{array}$ & 2 & - & - & - & 2 \\
\hline $\begin{array}{l}\text { horizontal neck banding and } \\
\text { three vertical appliqued ridges }\end{array}$ & 1 & - & - & - & 1 \\
\hline $\begin{array}{l}\text { horizontal neck banding and } \\
\text { appliqued node below neck } \\
\text { banding (on body) }\end{array}$ & 2 & - & - & - & 2 \\
\hline $\begin{array}{l}\text { horizontal neck banding and } \\
\text { vertical appliqued ridge } \\
\text { below neck banding (on body) }\end{array}$ & 1 & - & - & - & 1 \\
\hline \multicolumn{6}{|l|}{ Neck Banded-Punctated } \\
\hline $\begin{array}{l}\text { tool punctated row below lip and } \\
\text { horizontal neck banding on rim }\end{array}$ & 1 & - & - & - & 1 \\
\hline \multicolumn{6}{|l|}{ Punctated } \\
\hline fingernail punctated, diagonal rows & 1 & - & - & - & 1 \\
\hline linear tool punctated row & - & 1 & - & - & 1 \\
\hline tool punctated row below lip & 1 & - & - & - & 1 \\
\hline tool punctated rows & 1 & 5 & - & - & 6 \\
\hline Totals & 43 & 99 & 2 & 5 & 149 \\
\hline
\end{tabular}

$\mathrm{L}-\mathrm{R}=$ left to right lines; $\mathrm{R}-\mathrm{L}=$ right to left lines

The brushed and brushed-incised sherds only comprise 5.4 percent of the utility ware sherds at the Winterbauer site (see Tables 1 and 2). These sherds are from Bullard Brushed jars.

The three rims with horizontal grooved lines are a distinctive part of the utility ware assemblage. Utility ware jar sherds with grooved decorative elements (i.e., from Lindsey Grooved vessels, see Marceaux 2011) are distributed in two clusters of Caddo sites in the upper Neches and Angelina river basins. These sites all date after ca. A.D. 1680 to ca. A.D. 1750 and are historic Caddo sites associated with the Allen phase. The grooved sherds from the Winterbauer site in the upper Sabine River basin likely represents parts of vessels that were manufactured in one or the other of the two identified spatial clusters, and suggest that the site was occupied into the early historic period.

The incised and incised-punctated sherds in the utility ware assemblage are primarily from Maydelle Incised vessels with sets of cross-hatched, diagonal, and diagonal opposed lines on the rim or incised triangles filled with punctations (see Figure 3b-c). One rim has a single horizontal incised line under the vessel lip (see Figure 3a). 


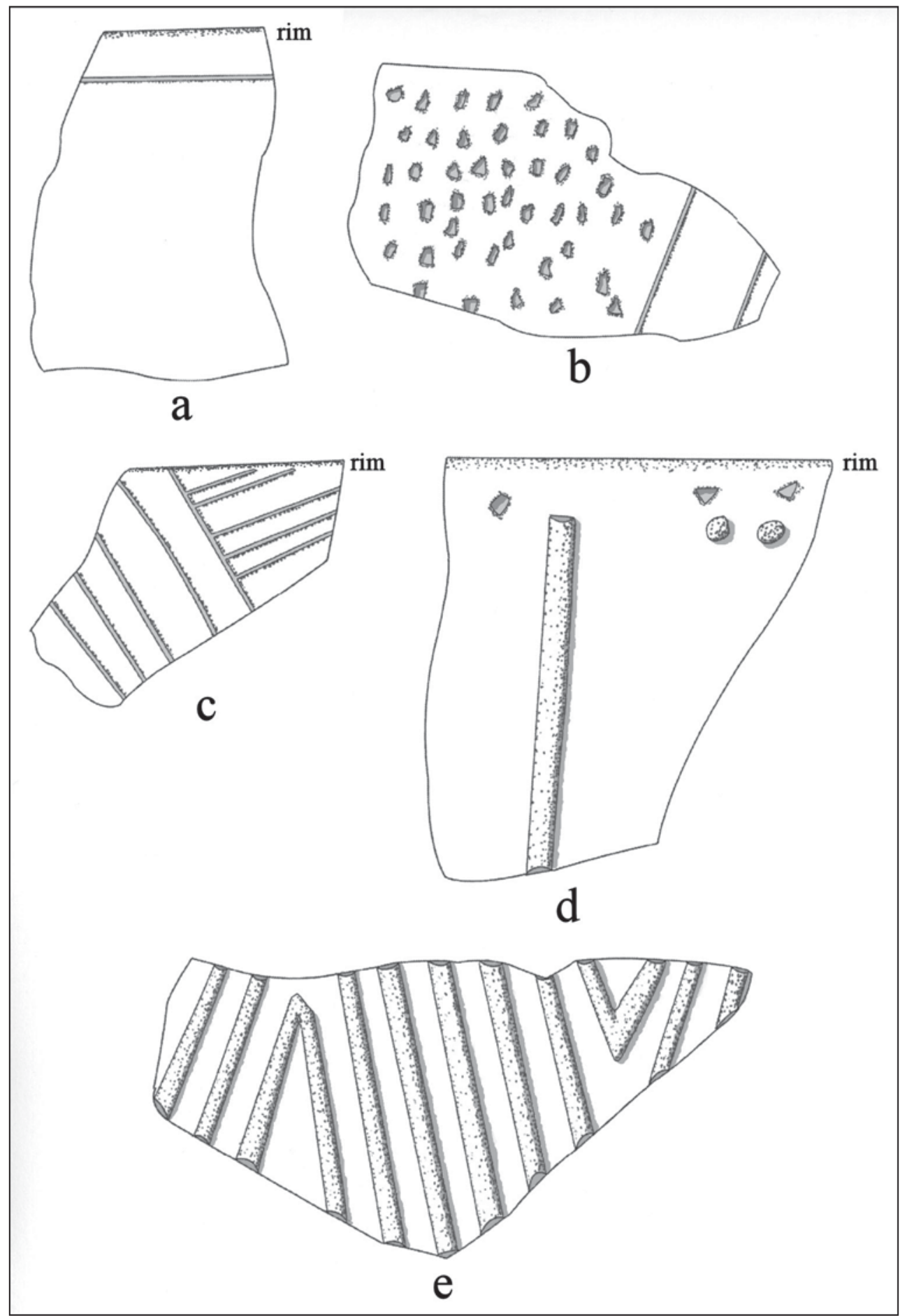

Figure 3. Selected decorative elements in the utility wares from the L. L. Winterbauer site: a, incised rim; b, incised-punctated body sherd; c, diagonal opposed incised rim sherd; d, appliqued-punctated rim sherd; e, appliqued body sherd (Cass Appliqued).

There are two lip notched rim sherds (see Table 2); the rims themselves are plain. Lip notched vessels are most common in post-A.D. 1400 Caddo ceramic assemblages in East Texas, especially in the middle Sabine, middle Red, upper Neches, and Angelina River basins (Perttula 2015:Figure 9). 
The neck banded, neck banded-appliqued, and neck banded-punctated rim and body sherds comprise 42 percent of the utility ware sherds from the L. L. Winterbauer site (see Table 2). These are all from La Rue Neck Banded jars, which are almost exclusively grog/bone-tempered. These wares are found in sites in the upper Neches and upper Sabine River basins in Frankston (ca. A.D. 1400-1650) and Titus phase (ca. A.D. 1430-1680) contexts and in Titus phase ceramic assemblages in the Big Cypress Creek basin (see Perttula 2015:Figure 10).

The fingernail and tool punctated rim sherds are a common characteristic of Titus phase assemblages in East Texas; they represent 6 percent of the L. L. Winterbauer assemblage (see Figure 2). These may be from Mockingbird Punctated jars (Perttula et al. 1998), but larger sherds (i.e., sherds that show the punctated rows on the rim and a plain body) are needed to make that typological identification.

About 88 percent of the fine ware sherds from the L. L. Winterbauer site are from vessels with engraved decorative elements (Table 3). Most of the decorative elements are from several varieties of Ripley Engraved carinated bowls (Figures 4a, d-f and 5c-d, g-h), while other sherds may well be from Ripley Engraved vessels, but the decorative elements are not typologically definitive. One grog-tempered rim is from a Taylor Engraved carinated bowl (Figure 4d); a red pigment has been rubbed in the engraved lines. Other engraved sherds have cross-hatched zones and excised triangles (Figure 5b), hatched zones, horizontal and vertical engraved lines (Figures $4 \mathrm{~b}$ and 5f), horizontal, vertical, and semi-circular lines (with tick marks) (Figure 4c), excised brackets (Figure 5e), excised brackets and horizontal-diagonal lines (Figure 5i), and slanting scroll lines (Figure 4a).

Table 3. Decorative elements in fine ware sherds from the L. L. Winterbauer site.

\begin{tabular}{|c|c|c|c|c|c|}
\hline \multirow[b]{2}{*}{ Decorative method } & \multicolumn{2}{|c|}{ Grog } & \multicolumn{2}{|c|}{ Bone } & \multirow[b]{2}{*}{$\mathrm{N}$} \\
\hline & rim & body & rim & body & \\
\hline \multicolumn{6}{|l|}{ Engraved } \\
\hline circle with excised rays & - & 1 & - & - & 1 \\
\hline $\begin{array}{l}\text { cross-hatched bracket and } \\
\text { curvilinear lines }\end{array}$ & - & 1 & - & - & 1 \\
\hline cross-hatched zone & 1 & - & - & - & 1 \\
\hline curvilinear line and excised zone & - & $1^{*}$ & - & - & 1 \\
\hline diagonal hatched zone & - & - & 1 & - & 1 \\
\hline horizontal lines & 3 & 2 & - & - & 5 \\
\hline $\begin{array}{l}\text { horizontal line and cross- } \\
\text { hatched bracket or hatched brackets }\end{array}$ & 1 & 4 & - & - & 5 \\
\hline $\begin{array}{l}\text { horizontal lines and excised } \\
\text { bracket and excised triangle }\end{array}$ & - & 1 & - & - & 1 \\
\hline horizontal and curvilinear lines & 1 & - & - & - & 1 \\
\hline $\begin{array}{l}\text { horizontal and curvilinear lines } \\
\text { and hatched zone }\end{array}$ & - & 1 & - & - & 1 \\
\hline horizontal and diagonal lines & - & 1 & - & - & 1 \\
\hline $\begin{array}{l}\text { horizontal and diagonal lines } \\
\text { and excised bracket }\end{array}$ & - & 1 & - & - & 1 \\
\hline $\begin{array}{l}\text { horizontal, diagonal, and } \\
\text { curvilinear lines }\end{array}$ & - & 1 & - & - & 1 \\
\hline
\end{tabular}


Table 3. Decorative elements in fine ware sherds from the L. L. Winterbauer site, cont.

\begin{tabular}{|c|c|c|c|c|c|}
\hline \multirow[b]{2}{*}{ Decorative method } & \multicolumn{2}{|c|}{ Grog } & \multicolumn{2}{|c|}{ Bone } & \multirow[b]{2}{*}{$\mathrm{N}$} \\
\hline & rim & body & rim & body & \\
\hline horizontal and vertical lines & 2 & 2 & - & - & 4 \\
\hline $\begin{array}{l}\text { horizontal, vertical, and semi- } \\
\text { circular lines, one with tick marks }\end{array}$ & 1 & - & - & - & 1 \\
\hline interlocking horizontal scroll line & 1 & 1 & - & - & 2 \\
\hline parallel lines & - & 5 & - & - & 5 \\
\hline scroll and circle elements & 1 & - & - & - & 1 \\
\hline slanting scroll lines & 2 & 1 & - & - & 3 \\
\hline straight line & - & 11 & - & 1 & 12 \\
\hline $\begin{array}{l}\text { SZ element and semi-circle with } \\
\text { excised pendant triangles }\end{array}$ & - & 1 & - & - & 1 \\
\hline Taylor Engraved hooked arm el. & 1 & - & - & - & 1 \\
\hline $\begin{array}{l}\text { vertical zone with cross-hatched } \\
\text { brackets, semi-circles, and open } \\
\text { and excised triangles; hatched } \\
\text { triangle within semi-circle }\end{array}$ & - & 1 & - & - & 1 \\
\hline \multicolumn{6}{|l|}{ Red-Slipped } \\
\hline ext. red-slipped & - & 3 & - & 1 & 4 \\
\hline int./ext. red-slipped & - & 3 & - & - & 3 \\
\hline Totals & 14 & 42 & 1 & 2 & 59 \\
\hline
\end{tabular}

*red-slipped

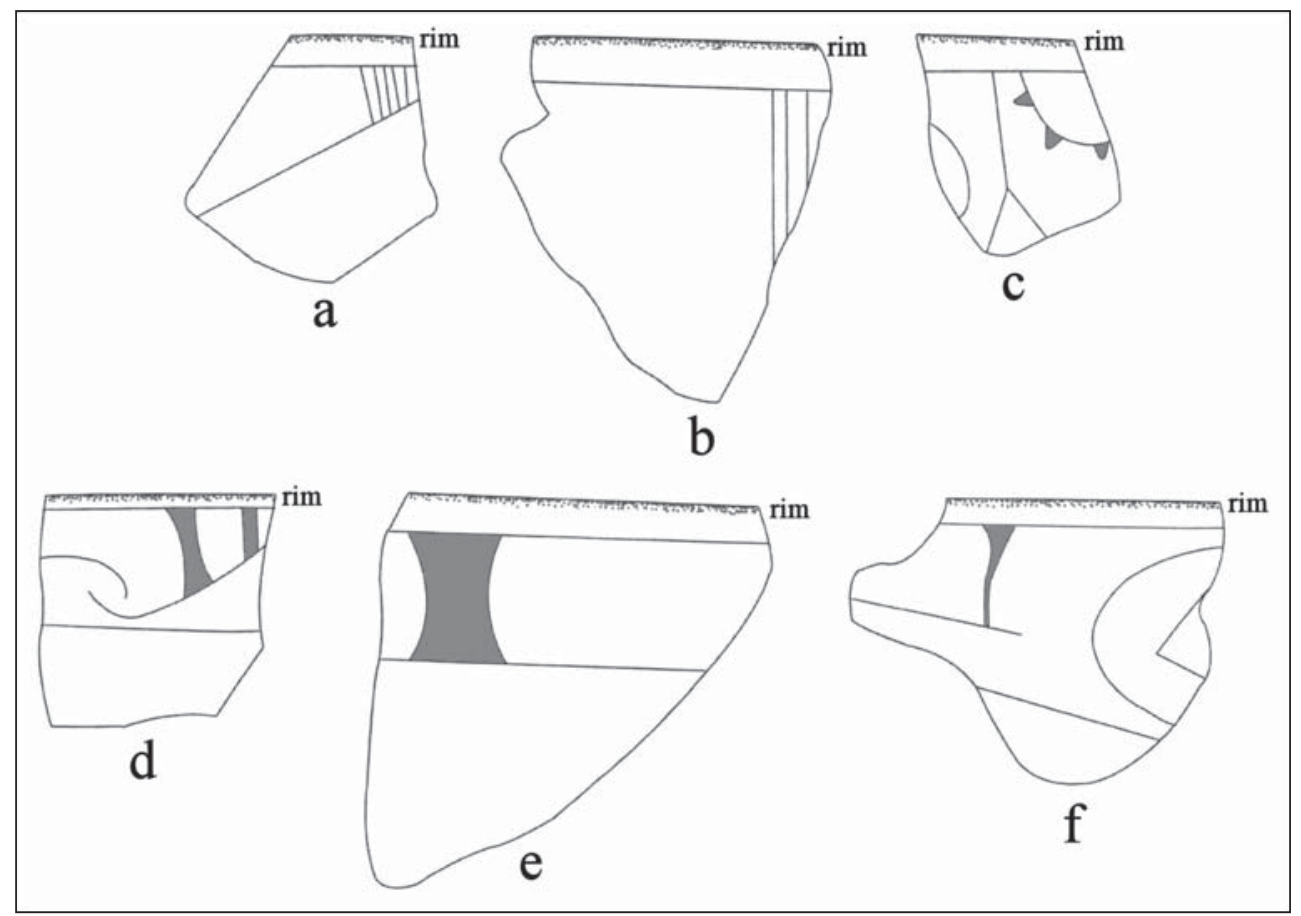

Figure 4. Selected decorative elements on fine ware rim sherds from the L.L. Winterbauer site. 


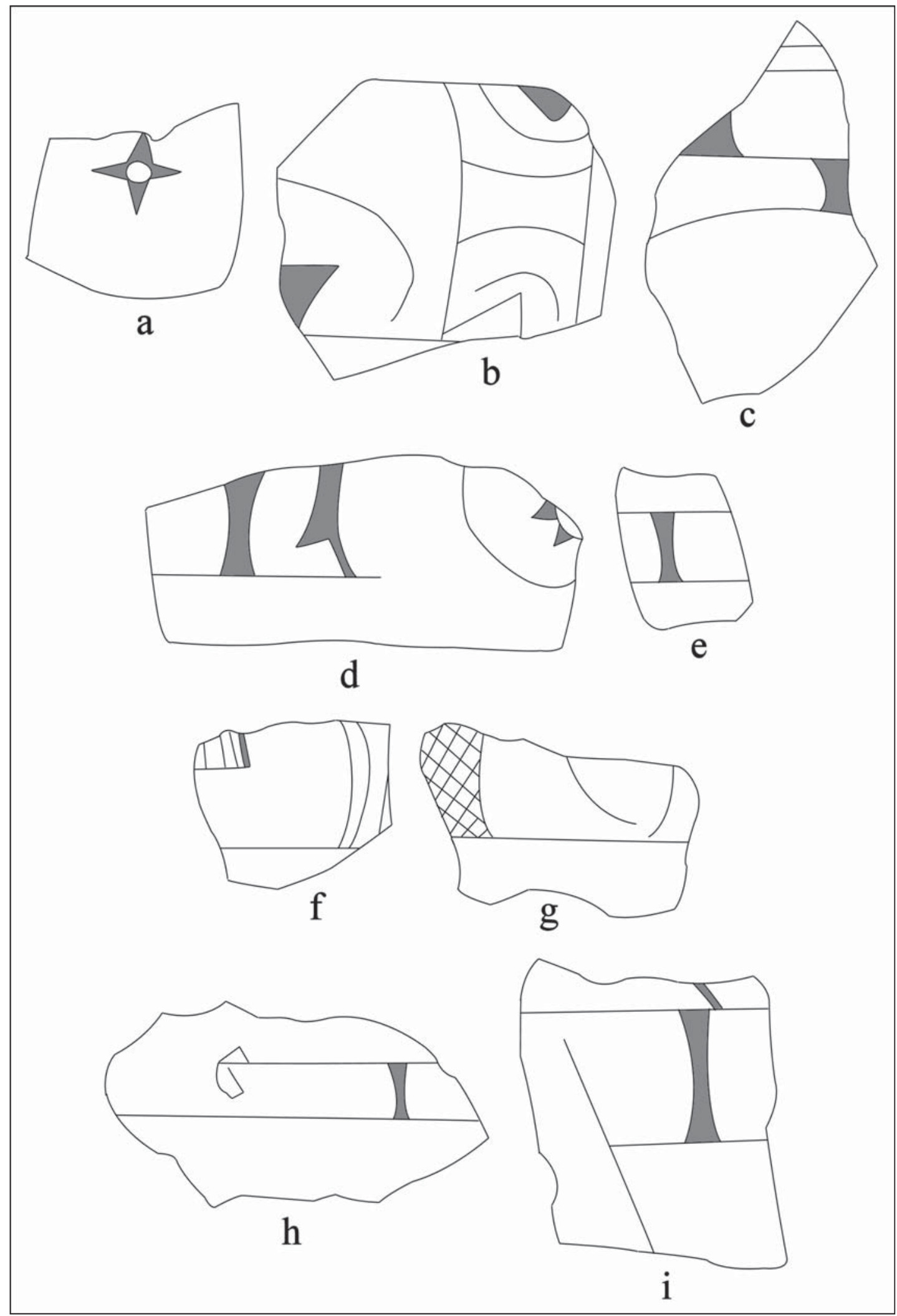

Figure 5. Selected decorative elements on fine ware body sherds from the L. L. Winterbauer site. 
Identified varieties of Ripley Engraved in the L. L. Winterbauer ceramic assemblage include var. Cash (see Figure 5a), var. Galt (central circle element (see Figures 4f), var. Pilgrims (interlocking horizontal scroll) (see Figures $4 \mathrm{e}$ and 5c), var. Pine Tree (see Figure 5d, g), and var. Richey (see Figure 5h) (see Fields et al. 2014:Table 8-6). Other rim and body sherds have either cross-hatched or excised upper and lower bracket elements, and these are probably from either var. Galt or var. Carpenter carinated bowls (see Figures 4a and $5 \mathrm{e}, \mathrm{i}$ ). One unique carinated bowl sherd has a vertical zone filled with a cross-hatched bracket, semicircular lines, and open and excised pendant triangles, as well as a semi-circular line and hatched pendant triangle (see Figure 5b). The absence of the pendant triangle motif (Ripley Engraved, var. McKinney), as well as fine ware types such as Keno Trailed suggests that the Titus phase occupation at the Winterbauer site likely pre-dates ca. A.D. 1600.

Only one of the engraved sherds (1.9 percent) is from a vessel with a red slip. Including the previously mentioned Taylor Engraved rim sherd (see Figure 4d), 7.7 percent of the engraved sherds have had a red pigment rubbed in the engraved lines; another 3.8 of the engraved sherds have a white clay pigment rubbed in the engraved lines. About 12 percent of the fine ware sherds have a red-slipped decoration, the slip applied to either one or both surfaces of vessels (see Table 3). Two of the sherds are from red-slipped bottles. Other Late Caddo period sites where red-slipped sherds are common in assemblages include Titus phase sites in the Big Cypress and upper Sabine River basins and 41HP175 in the upper Sulphur River basin (see Perttula 2015:Table 1).

\section{Bone Tools}

There are several different kinds of bone tools from the midden mound at the Winterbauer site. This includes two beveled gouges (Figure 6a, d), three antler or bone flakers (Figure 6b-c, e), and two deer ulna awls (Figure 6f-g); the deer ulna awls have beveled work areas at the distal margins of the tools.

The gouges range from 60-61.5 $\mathrm{mm}$ in length and $13.5 \mathrm{~mm}$ in width, with the beveling confined to the distal tool margin (see Figure 6a, d). The flakers range from 54-91 mm in length and 9-20.5 mm in width (see Figure 6b-c, e); one antler flaker tool had been burned before it was shaped into a working tool. The deer ulna awls range from $70-96 \mathrm{~mm}$ in length and $24-25 \mathrm{~mm}$ in width.

\section{Mussel Shell Zoomorphic Pendant}

Likely the most distinctive artifact recovered in the excavations at the Winterbauer site is a zoomorphic pendant carved from a fresh water mussel shell valve (Figure 7; see also Jackson 1935:Plate 3a). The pendant is $62.1 \mathrm{~mm}$ in length, $25.0 \mathrm{~mm}$ in width, and $3.3 \mathrm{~mm}$ in thickness.

The pendant has a clearly defined head with three slightly drilled holes to mark the eyes and nose of the zoomorph. The zoomorph's body is defined by upper and lower horizontal engraved lines and notches along the shell margin, and there is an engraved diamond element centered on the body (see Figure 7); there are opposed notches on the shell valve's margin opposite the horizontal apex of the diamond. Finally, there are four short opposed diagonal lines near each of the sides of the diamond.

This style of zoomorphic pendant is viewed as a symbolically powerful object that may have been worn as a necklace or a single pendant centerpiece (McKinnon 2014). The most current interpretation of these pendants is that they are "part of a series of objects associated with broad cultural themes linked to thematic and mythic representations of turtles, specifically alligator snapping turtles and their characteristic diamondshaped plastrons" (McKinnon 2014:5). At the present time, there are only 16 sites in the entire Caddo area that have these zoomorphic pendants, and the pendant from the Winterbauer site is the southwestern one known in the entire corpus. The style of the Winterbauer pendant is virtually identical to pendants found 


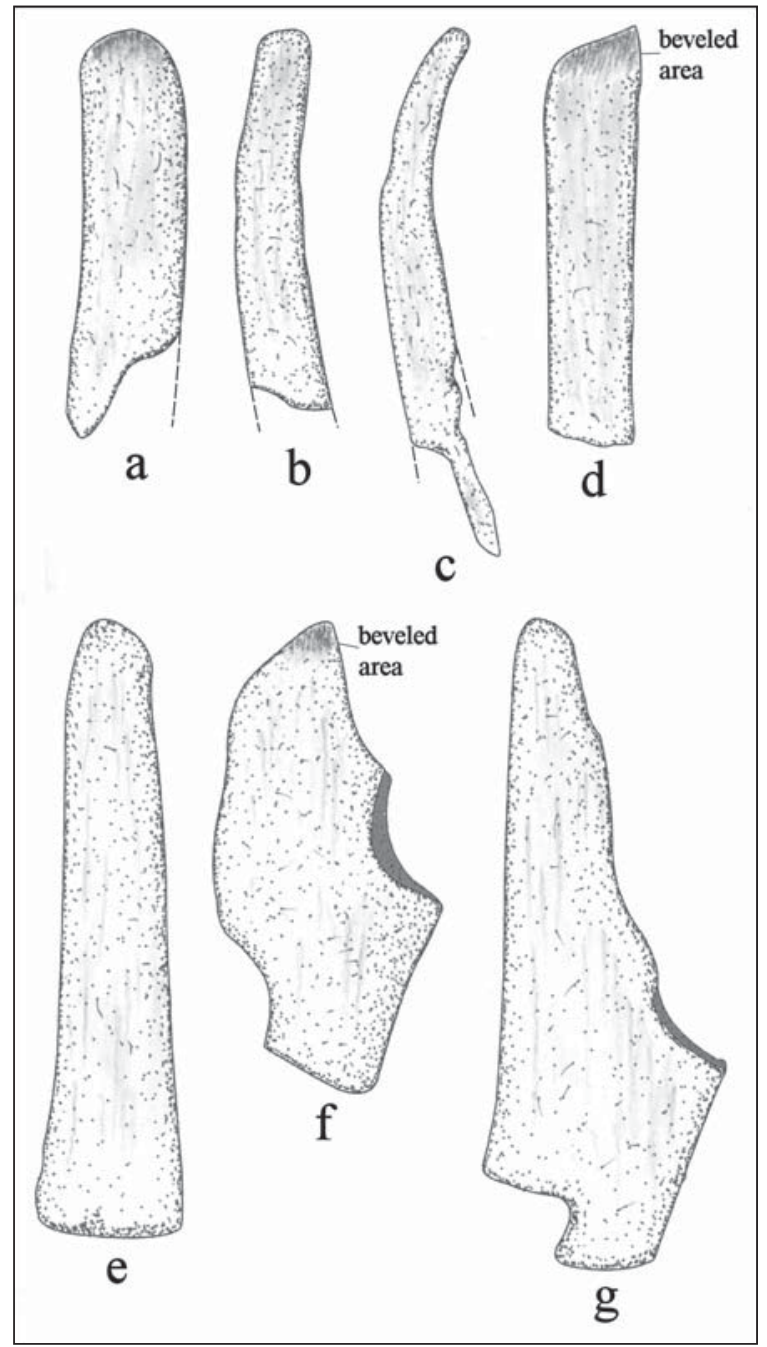

Figure 6. Bone tools from the Winterbauer site.

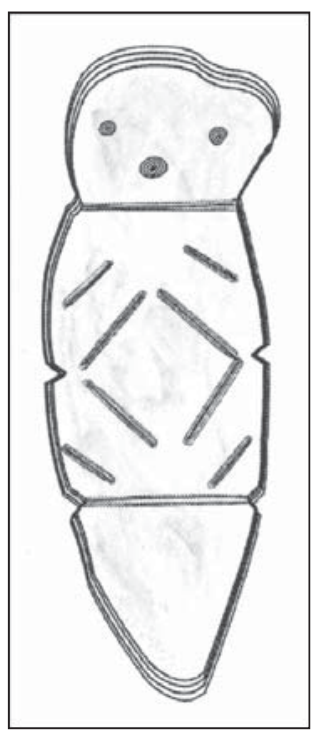

Figure 7. Mussel shell zoomorphic pendant from the L. L. Winterbauer site. 
along the Red River and in the Big Cypress Creek basin from burial contexts. McKinnon (2014:21) places the Winterbauer pendant in his Group B1, which is described as follows: "they are slender pendants with an engraved pattern of concentric parallelograms or diamonds, usually with a dot in the center. The upper portion, or "head," is typically rounded with perforations or "eyes" just below the top of the head."

\section{SUMMARY AND CONCLUSIONS}

The L. L. Winterbauer site is a Late Caddo period Titus phase (ca. A.D. 1430-1550) habitation site along a tributary stream in the Lake Fork Creek basin of the East Texas Post Oak Savannah. Titus phase habitation sites with midden mounds and family cemeteries are quite abundant in this part of the Lake Fork Creek basin as well as in adjoining drainages not far to the west and east (Bruseth and Perttula 1981; Perttula et al. 1993), suggesting a sizeable population of ancestral Caddo farming groups lived in this part of East Texas after the early 15 th century A.D.

Wilson and A. T. Jackson investigated the midden mound at the L. L. Winterbauer site in 1930. Other than a number of canid (dog) burials marked by nine dog crania, the midden mound contained concentrations of ceramic sherds, animal bones, charcoal, and ashes in $0.6 \mathrm{~m}$ thick deposits, but no other features. The artifact assemblage recovered from the excavations in the midden mound at the Earl Jones Farm site includes ceramic sherds $(n=916)$, clay coils, several bone tools, and animal bones $(n=99)$ from canid, deer, bird turtle, and two possible bison bones. The most unique artifact recovered in the midden mound excavations was a zoomorphic pendant made from a fresh water mussel shell valve (see Figure 7). These pendants are rare finds across the entire Caddo area, as they have been documented at only 16 sites (mostly on the Red River).

The ceramic sherds from the site are from grog-tempered plain ware, utility ware, and fine ware. This includes sherds from Bullard Brushed, Harleton Appliqued, Cass Appliqued, La Rue Neck Banded, McKinney Plain, and Maydelle Incised utility ware jars, as well as Ripley Engraved and Taylor Engraved fine ware carinated bowls and red-slipped carinated bowls and bottles.

\section{ACKNOWLEDGMENTS}

I am grateful for the help received from Jonathan Jarvis concerning access to the records and collections from the L. L. Winterbauer site at the Texas Archeological Research Laboratory at The University of Texas at Austin. Lance Trask prepared the figures for this article. I also appreciate Duncan McKinnon sharing his MS on Caddo zoomorphic pendants.

\section{REFERENCES CITED}

Bruseth, J. E. and T. K. Perttula

1981 Prehistoric Settlement Patterns at Lake Fork Reservoir. Texas Antiquities Permit Series, Report No. 2. Texas Antiquities Committee and Southern Methodist University, Austin and Dallas.

Jackson, A.T.

1935 Ornaments of the East Texas Indians. Bulletin of the Texas Archeological and Paleontological Society $7: 11-28$.

Marceaux, P. S.

2011 The Archaeology and Ethnohistory of the Hasinai Caddo: Material Culture and the Course of European Contact. Ph.D. dissertation, Department of Anthropology, The University of Texas at Austin. 
McKinnon, D. P.

2014 Zoomorphic Effigy Pendants: An Examination of Style, Medium, and Distribution in the Caddo Area. MS on file with the author.

Perttula, T. K.

2015 East Texas Caddo Ceramic Sherd Database. Journal of Northeast Texas Archaeology 51, in press.

Perttula, T. K., B. D. Skiles, and B. C. Yates

1993 The Goldsmith Site (41WD208): Investigations of the Titus Phase in the Upper Sabine River Basin, Northeast Texas. Bulletin of the Texas Archeological Society 61:139-191.

Perttula, T. K., M. Tate, H. Neff, J. W. Cogswell, M.D. Glascock, E. Skokan, S. Mulholland, R. Rogers, and B. Nelson 1998 Analysis of the Titus Phase Mortuary Assemblage at the Mockingbird Site Kahbakayammaahin" (41TT550). Document No. 970849. Espey, Huston \& Associates, Inc., Austin.

Suhm, D. A. and E. B. Jelks (editors)

1962 Handbook of Texas Archeology: Type Descriptions. Special Publication No. 1, Texas Archeological Society, and Bulletin No. 4, Texas Memorial Museum, Austin. Reprinted in 2009, Gustav's Library, Davenport, Iowa.

Wilson, A. M. and A. T. Jackson

1930 Field Notes: Work Done at Indian Sites, Wood County, Texas. MS on file, Texas Archeological Research Laboratory, The University of Texas at Austin. 